\title{
ОПТИМІЗАЦІЯ СИСТЕМИ НАВЧАННЯ ІНОЗЕМНОЇ МОВИ КУРСАНТІВ ЗАКЛАДІВ ВИЩОЇ ОСВІТИ МВС
}

\author{
Краснова Н. В. \\ старший викладач кафедри іноземних мов \\ Харківський національний університет внутрішніх справ \\ пр. Льва Ландау, 27, Харків, Україна \\ orcid.org/0000-0003-1986-9083 \\ natysja2005@rambler.ru \\ Бабак Г. С. \\ викладач кафедри іноземних мов \\ Харківський начіональний університет внутрішніх справ \\ пр. Льва Ландау, 27, Харків, Україна \\ orcid.org/0000-0003-3124-8212 \\ super.anna230@ukr.net \\ Сорокіна Г. М. \\ старший викладач кафедри іноземних мов \\ Харківський національний університет внутрішніх справ \\ пр. Льва Ландау, 27, Харків, Українаогсіd.org/0000-0001-8046-9041 \\ Gallina_1012@ukr.net
}

\begin{abstract}
Ключові слова: заклад вищзої освіти МВС, іноземна мова, курсант, система навчання, професійно-особистісні якості, метод навчання, педагогічне спілкування, критерії контролю, інтерактивний метод навчання.
\end{abstract}

У статті розглядається оптимізація системи навчання іноземної мови курсантів закладів вищої освіти МВС. Вимоги сучасного світу спонукають нас до перегляду й удосконалення пріоритетів та напрямів професійної підготовки майбутніх офіцерів правозахисних органів і фахівців правової сфери, до формування необхідних навичок, серед яких особливе місце посідає знання іноземної мови. Система іншомовної освіти курсантів побудована на основі теорії управління, що дає змогу оптимізувати навчання іноземної мови у закладах вищої освіти МВС за такими взаємопов'язаними компонентами, як: мета (соціальне замовлення, втілення в нормативних документах); викладач (професійно-особистісні якості, співвіднесені зі структурою педагогічної діяльності); засоби управління (зміст навчання, навчально-методичний комплекс, метод навчання, педагогічне спілкування, критерії контролю); той, що навчається (особистісні характеристики, співвіднесені зі структурою вчення); іншомовна освіченість як результат функціонування системи; контроль і самоконтроль (зворотні зв'язки); зовнішні впливи (вплив середовища).

У статті також наголошується на необхідності враховувати специфічні умови навчання у закладах вищої освіти МВС під час організації навчального процесу та викладання іноземної мови.

Авторами статті проведено аналіз сучасних досліджень та публікацій щодо питань із вирішення проблем успішності навчання іноземної мови у вищій школі, який відображає неможливість повною мірою реалізувати виховний, освітній і розвиваючий потенціал навчання, якщо діяльність викладачів не націлена на постійний пошук найбільш оптимальних для заданих умов шляхів вирішення педагогічних завдань, та визначено актуальність дослідницьких завдань, які вимагають суттєвих змін в освітній системі. 
3'ясовано, що зміна пріоритетів із пасивного володіння мовою (читання) на активне, з розвитком усіх видів мовленнєвої діяльності, вимагає зміни системи навчання, а не окремих різнопланових заходів; відсутні педагогічні дослідження, де в межах системного цілісного підходу розглядалася би проблема оптимізації навчання іноземної мови; не досліджена повною мірою специфіка навчання іноземних мов у закладах вищої освіти МВС.

\title{
OPTIMIZATION OF THE FOREIGN LANGUAGE TEACHING SYSTEM OF CADETS OF HIGHER EDUCATION INSTITUTIONS OF THE MINISTRY OF INTERNAL AFFAIRS
}

\author{
Krasnova N. V. \\ Senior Lecturer at the Department of Foreign Languages \\ Kharkiv National University of Internal Affairs \\ Lva Landau ave., 27, Kharkiv, Ukraine \\ orcid.org/0000-0003-1986-9083 \\ natysja2005@rambler.ru
}

Babak G. S.

Lecturer at the Department of Foreign Languages

Kharkiv National University of Internal Affairs

Lva Landau ave., 27, Kharkiv, Ukraine

orcid.org/0000-0003-3124-8212

super.anna230@ukr.net

Sorokina H. M.

Senior Lecturer at the Department of Foreign Languages

Kharkiv National University of Internal Affairs

Lva Landau ave., 27, Kharkiv, Ukraine

orcid.org/0000-0001-8046-9041

Gallina_1012@ukr.net

Key words: higher education institution of the Ministry of Internal Affairs, foreign language, cadet, training system, professional and personal qualities, teaching method, pedagogical communication, control criteria, interactive teaching method.
The article considers the optimization of the system of teaching a foreign language to cadets of higher education institutions of the Ministry of Internal Affairs. The requirements of the modern world motivate us to revise and improve the priorities and areas of future law enforcement officers training and to form the necessary skills, among which a special place is given to of a foreign language learning. The system of foreign language education of cadets is built on the basis of management theory, which allows to optimize foreign language teaching in higher education institutions of the Ministry of Internal Affairs on the following interrelated components: purpose (social order, implementation in regulations); teacher (professional and personal qualities, correlated with the structure of pedagogical activity); management tools (learning content, educational and methodological complex, teaching method, pedagogical communication, control criteria); the learner (personal characteristics correlated with the structure of teaching); foreign language education as a result of the functioning of the system; control and self-control (feedback); external influences (environmental influences).

The article also emphasizes the need to take into account the specific conditions of study in higher education institutions of the Ministry of Internal Affairs when organizing the educational process and teaching foreign language. 
The authors of the article analyzed current research and publications on solving problems of foreign language teaching in higher education, which reflects the inability to fully realize the educational and developmental potential of teaching, if teachers are not aimed at constantly finding the most optimal solutions of pedagogical tasks and the relevance of research tasks that require significant changes in the educational system.

It was found that the change of priorities from passive language proficiency (reading) to active, with the development of all types of speech activity, requires a change in the learning system, rather than some different activities; there are no pedagogical researches, where within the framework of the system holistic approach the problem of optimization of foreign language learning would be considered; the specifics of teaching foreign languages in higher education institutions of the Ministry of Internal Affairs have not been fully studied.

Постановка проблеми. Оптимізація системи навчання іноземної мови курсантів закладів вищої освіти МВС є невід'ємною складовою частиною підготовки здобувачів вищої освіти ступеня бакалавра та магістра, які відповідно до Національної рамки кваліфікацій повинні мати рівень володіння іноземною мовою, що дозволяє їм продовжувати навчання та вести професійну діяльність в іншомовному середовищі. Курсанти, які закінчили курс навчання іноземної мови, повинні володіти орфографічною, орфоепічною, лексичною, граматичною та стилістичною нормами мови, яку вони вивчають, у межах програмних вимог і правильно використовувати їх у всіх видах мовленнєвої комунікації, в науковій сфері у формі усного та писемного спілкування.

Те, що відбувається сьогодні у світовому співтоваристві, - це процеси глобалізації суспільного життя (об'єднання багатонаціональної Свропи; інтеграція національних освітніх систем у світовий культурно-освітній простір; стрімкий розвиток інформаційної мережі Інтернет тощо). Вони супроводжуються загостренням таких загальносвітових проблем, як міжнародна злочинність і тероризм. У цих умовах знання іноземних мов стає необхідним засобом для встановлення і розвитку міжнаціональної та міжкультурної комунікації, що виводить предмет «іноземна мова» на новий рівень у сфері загальної та професійної освіти, особливо у закладах вищої освіти МВС. Сьогодні знання іноземної мови має значний вплив на професійну діяльність правоохоронця. Одна із центральних проблем педагогічної науки i практики - професійна підготовка майбутніх фахівців. Перед державою і суспільством стоїть складне завдання вдосконалення системи, змісту і методів освіти, виховання особистості фахівця, компетентного у своїй професії, що постійно займається підвищенням рівня кваліфікації, вміє приймати рішення і брати відповідальність на себе, здатен впливати на розвиток суспільства.

Однак, як показує практика, нині яскраво проявляється протиріччя між потребою суспільства у фахівцях органів внутрішніх справ, які володіють іноземними мовами, і нездатністю наявної системи навчання у закладах вищої освіти МВС забезпечити необхідну підготовку. Подолання цього протиріччя можливе у разі оптимізації цілісної системи навчання іноземних мов у закладах вищої освіти МВС України.

Метою статті $\epsilon$ висвітлення можливостей формування професійної іншомовної комунікативної компетентності майбутніх фахівців у закладах вищої освіти завдяки оптимізації системи навчання іноземної мови, використанню інноваційних педагогічних технологій, сучасних комп'ютерних технологій.

Аналіз останніх досліджень і публікацій. На думку Р.О. Гришкової, підготовка майбутніх фахівців у 3ВО в соціокультурному контексті, 3 одного боку, передбачає формування у суб'єктів навчання толерантності до інших людей, розуміння їхніх традицій, звичок, особливостей ведення бізнесу, національних цінностей тощо. 3 іншого боку, такі знання сприяють формуванню у студентів стійкого позитивного ставлення до іншомовної культури та вивчення іноземної мови. Водночас вивчення чужої мови і культури сприяє формуванню національної самосвідомості студента [2, с. 424].

Нині є велика кількість наукових досліджень, у яких робляться спроби вирішити проблему успішності навчання шляхом удосконалення окремих його сторін: особистості і діяльності викладача іноземної мови (Г.А. Лобич, О.В. Салкова, Стафуріна, І.Б. Трубнікова, Т.Г. Шарухіна); особистості і навчальної діяльності учня (JI.А. Бріткова, І.Ю. Бруслова, Е.А. Іванова, ЈІ.В. Марігцук, Л.П. Меркулова, Л.Н. Румянцева, В.В. Шарай); взаємодії тих, хто навчає, і тих, хто навчається (Т.Н. Круглова, В.П. Феофілова, А.В. Фомін); системи контролю і самоконтролю (Е.П. Бочарова, М.Є. Пахомкіна, І.В. Столярова); використання технічних засобів (М.А. Акопова, А.Н. Бикова); аспектів навчання (Л.Ф. Кропивник - монологічне мовлення, Л.В. Марищук - лексика, Г.Н. Оловяннікова - читання, Т.В. Сущева - фонетика тощо). $\mathrm{У}$ цих роботах узагальнено багатий практичний досвід, вони містять безліч рекомендацій щодо способів поліпшення якості навчання і підвищення його ефективності.

Виклад основного матеріалу дослідження. Однак ні велика кількість досліджень, ні успіхи, 
досягнуті їх авторами, поки не привели до радикальної зміни ситуації в навчанні іноземних мов у немовних вищих навчальних закладах, зокрема у закладах вищої освіти МВС.

Це зумовлено декількома причинами: по-перше, зміна пріоритетів із пасивного володіння мовою (читання) на активне, 3 розвитком усіх видів мовленнєвої діяльності, вимагає зміни системи навчання, а не окремих різнопланових заходів; по-друге, відсутні педагогічні дослідження, в яких у рамках системного цілісного підходу розглядалася би проблема оптимізації навчання іноземної мови; по-третє, не досліджена повною мірою специфіка навчання іноземнх мов у закладах вищої освіти МBC, а отже, в наукових розробках не враховуються належним чином потреби і проблеми курсантів і слухачів цих навчальних закладів.

Вся сукупність зовнішніх умов, що мають вплив на суб'єктів освітнього процесу, може бути розділена на дві групи: умови, в яких безпосередньо протікає навчальний процес, і позанавчальні умови, в кожній 3 яких виділяються чотири взаємопов'язаних складових частини: психологічна, гігієнічна, адміністративно-організаційна, матеріальна. Умови, в яких протікає навчальний процес, є специфічними умовами закладу вищої освіти МВС.

Компонентами, що мають найбільший вплив на курсантів, є: вплив із боку навчальної групи (групова мотивація навчання, різка неоднорідність груп за рівнем навченості курсантів іноземної мови, переповненість чи недокомплект); процес адаптації до умов навчання у закладі вищої освіти МВС, що збігається з періодом вивчення іноземної мови; неадекватність часу, відведеного на вивчення іноземної мови, завданням, поставленим програмою, й умовам навчання; становище навчального предмета в розкладі занять; тривалий робочий день; нераціональна організація самопідготовки; необхідність виконання численних службових обов'язків; наявність чи відсутність програм курсантських обмінів із відповідними навчальними закладами за кордоном; навчально-матеріальна база вищого навчального закладу.

Для викладача найбільш суттєві складники зумовлені характером особистісно-професійних взаємин у кафедральному колективі, умовами праці та відпочинку в навчальному закладі, можливістю чи неможливістю проходження стажування в країні, де викладається мова.

Позанавчальні умови для курсантів і викладачів складаються з побутових умов; морально-психологічної обстановки в родині (гуртожитку); престижності чи непрестижності професії, що викладається/вивчається, у суспільстві і найближчому оточенні; наявності чи відсутності мате- ріальних засобів для самостійного підвищення кваліфікації в мові і для нормального існування взагалі; державної мовної політики.

У науковій літературі, присвяченій проблемі навчання іноземних мов, ретроспективи методів, підходів, систем самого різного рівня, глибини i виду, як вітчизняних, так і зарубіжних, представлені досить широко. Узагальнення інформації, отриманої під час аналізу цих джерел, дало змогу виділити у вітчизняній дидактиці три основних, найбільш розроблених напрями в навчанні іноземних мов, які можуть розглядатися як системи, потенційно придатні для вирішення завдання оптимізації педагогічної системи навчання іноземної мови курсантів у закладах вищої освіти МВС. Це «офіційний» - свідомо-практичний напрям, система інтенсивного навчання Г.А. Китайгородської та комунікативне спрямування, розроблене Є.I. Пассова і його науковою школою. У наші дні завдання вищих навчальних закладів - підготовка не лише спеціалістів, а й людей, які зможуть почуватися впевнено у світі безперестанних технологічних змін і переворотів, у світі, де досить часто доведеться стикатися із ситуаціями вибору та прийняття рішень, що торкаються життєвих інтересів як самих цих людей, так і багатьох інших. Таким чином, у сучасному суспільстві у вищої освіти дві ролі: перша - традиційна, пов'язана із підготовкою спеціалістів, друга - гуманітарна, пов'язана з розвитком людської особистості [3, с. 90].

Створена багато років назад система свідомо-практичного навчання іноземних мов була покликана замінити порівняльний метод, який панував у той час. У рамках цієї системи, орієнтованої на практичне активне оволодіння іноземною мовою, передбачалося усвідомлення мовних явищ і функціонування в мові фонетичного, лексичного та граматичного матеріалу відповідно до ситуації спілкування, набуття практичних знань як бази самоконтролю і самокорекції. Елементи свідомості слід підкріплювати інтуїтивно-імітативними прийомами роботи. Передбачалося, що рідна мова повинна слугувати учню для усвідомлення явищ мови, що вивчається, в зіставленні 3 рідною. Чуттєво-наочний етап у навчанні повинен був забезпечуватися застосуванням аудіовізуальних засобів. Побудова проблемної ситуації саме на наочній основі, з використанням цікавих вербально-зображальних опор, має відповідати вимогам, що співвідносяться з комунікативно-пізнавальними потребами та можливостями студентів $[4$, с. 120]. Варто додати, що використання методів проблемного навчання може бути менш ефективним у разі відсутності додаткових матеріалів іноземною мовою, що допомагають візуалізувати та проаналізувати завдання, поставлене 
викладачем. Такими матеріалами можуть бути ролики з інтернету за темою або відеоматеріали, що містять більш детальну інформацію про проблему. Наявність достатньої інформації стимулюватиме активну дискусію та допоможе зробити реальні висновки щодо вирішення завдання, а також полегшити процес спілкування курсантів іноземною мовою. Під активністю в навчанні малася на увазі активність мислення курсантів, підтримувана адекватними прийомами навчання, прищепленням навичок самостійної роботи над мовою тощо. Практична спрямованість навчання іноземної мови передбачала вироблення умінь видобувати інформацію 3 письмових і усних джерел. 3 огляду на те, що на заняттях курсанти найчастіше чують мову в основному тільки свого викладача, то вона (мова) повинна бути за можливості зразковою в мовному відношенні і водночас цілком доступною для сприйняття і розуміння.

Одним із найважливіших методів навчання $\epsilon$ інтерактивний метод. Таке навчання зумовлює, що студент у процесі самостійної підготовки до занять (опрацювання необхідного лексичного, граматичного мінімуму, роботи 3 професійними текстами, аудіо- та відеоматеріалами, опрацювання англомовних Інтернет-ресурсів) навчається від викладача, інших студентів групи і розширює свій мовленнєвий досвід, читаючи, слухаючи, аналізуючи та коригуючи як власну, так і чужу інформацію [5, с. 352]. Метою застосування інтерактивних методів у процесі вивчення будь-якої дисципліни $є$ створення комфортних умов навчання, в яких усі студенти взаємодіють між собою. На заняттях створюється можливість обговорення різноманітних проблем, доведення, аргументування власного погляду, тобто відбувається взаємодія викладача і студента, яка орієнтує особистість на розвиток їі творчих і розумових здібностей та комунікативних навичок [6].

Наукова організація навчального процесу передбачала циклічність елементів, єдність завдань аудиторних, лабораторних i домашніх видів роботи, варіативність ланок системи навчання та гнучкість управління з боку навчального, облік індивідуальних особливостей учнів, вирішення проблеми кількісної та якісної конкретизації бажаних результатів навчання, а також необхідність навчити учнів самостійно працювати над іноземною мовою. Враховуючи ці елементи, ми можемо виділити комплекс специфічних факторів, що роблять найбільший вплив на успішність вивчення курсантами іноземних мов: тривалість робочого дня; необхідність виконання численних службових обов'язків; організація самопідготовки; процес адаптації до умов навчання у закладі вищої освіти МВС, що збігається з періодом вивчення іноземної мови; неадекватність часу, відведеного на вивчення іноземної мови, завданням, поставленим програмою і умовами навчання; «непрофільні» предмети, такі як «іноземна мова», в сукупності предметів вузівського циклу.

Незважаючи на очевидну привабливість заявлених принципів свідомо-активного методу, розвиток практики масового навчання іноземних мов не приніс очікуваних масштабних результатів. 3 одного боку, це можна було б пояснити закритістю кордонів у період «застою» і пов'язаною 3 цим «непотрібністю» іноземної мови загалом i розмовної мови зокрема, що поступово призвело до демотивованості учнів, статусу другорядного у предмета «іноземна мова», переважання читання і перекладу в навчанні іноземної мови в неспеціалізованих навчальних закладах. 3 іншого боку, це пов'язано, ймовірно, з великою інерційністю державної освітньої системи, 3 навчанням «по-старому», зі змінами в деталях, але не загалом, незважаючи на заявлені нові цілі.

Вирішенню завдань задоволення потреби суспільства і держави в сильних правоохоронних органах із високоосвіченими, кваліфікованими фахівцями підпорядкований розвиток освітніх установ у системі МВС. Діяльність ЗВО МВС спрямована на підвищення авторитету, загальної та професійної культури співробітників, формування їх здатності виконувати свій обов'язок у будь-яких ситуаціях, в утвердженні та відстоюванні моральних і правових цінностей. Сучасна правоохоронна діяльність вимагає всебічно розвиненої особистості, висококваліфікованого, культурного і ініціативного фахівця, який працює 3 повною віддачею, що володіє високою відповідальністю. Відмова від орієнтації на передачу абстрактних знань як головної мети професійної підготовки в процесі навчання, усвідомлення необхідності забезпечити формування особистості майбутнього професіонала, який володіє необхідною структурою професійних якостей, допомагає закладу вищої освіти МВС подолати розрив між соціальним замовленням і рівнем професійної підготовки. Ефективність цього процесу в чималому ступені залежить від знання методологічних основ навчання, оцінки нових форм і методів навчання та виховання 3 погляду їх можливостей у стимулюванні діяльності курсантів як на рівні зовнішньої результативності, так і з позицій внутрішнього гармонійного розвитку їх особистості.

Вплив на формування мотиваційної системи курсантів надає такий напрям, як підвищення значущості всіх навчальних дисциплін, у тому числі й іноземної мови, викладання якого в закладі вищої освіти МВС є професійно-орієнтованим. Завдання викладача іноземної мови - засобами свого предмета внести зміни в особистість 
курсанта, що відповідають вимогам професії. Вивчення іноземної мови може стати потужним чинником формування професійних мотивів у майбутніх співробітників поліції.

У нинішній економічній і соціально-політичній ситуації завдання зміцнення правоохоронних органів стають дуже актуальними. Ускладнення характеру оперативно-службових завдань, пов’язаних із діями факторів економічної та політичної криз, зростання організованої злочинності, протиправних проявів, міжнаціональних конфліктів i соціальних розбіжностей пред'являє до кадрів ОВС підвищені вимоги, гостро ставить проблему їх якісної підготовки 3 іноземної мови, умови впровадження в освітній процес 3ВО МВС України європейської комунікативної системи навчання іноземних мов, що вимагають реалізації їі положень по кожному 3 компонентів педагогічної системи, а також на різних рівнях управління системою навчання (нормативно-правовому, адміністративно-організаційному, навчально-методичному, матеріально-технічному, контрольно-оціночному, психологічному).

Висновки. Оптимізація системи навчання іноземної мови курсантів закладу вищої освіти МВС стає одним із факторів формування професійних мотивів. Професійна підготовка майбутніх офіцерів-юристів буде більш ефективною, якщо впровадити у практику викладання іноземної мови спеціальну педагогічну програму цілеспрямованого формування професійних мотивів, яка передбачає зміщення акценту на професійно-мотиваційний аспект і забезпечує: а) поглиблення професійного компонента у змісті навчання іноземної мови; б) вибір методів, форм і засобів навчання, адекватних щодо педагогічного процесу формування мотивів професійної діяльності; в) організацію диференційованого навчання іноземної мови 3 урахуванням змістовних і динамічних характеристик професійних мотивів курсантів.

\section{ЛІТЕРАТУРА}

1. Гришкова Р.О. Формування іншомовної соціокультурної компетенції студентів нефілологічних спеціальностей : монографія. Миколаїв : МДГУ ім. Петра Могили, 2007. 424 с.

2. Зюзіна Т. Науки про культуру та мистецтво в структурі гуманітарної університетської освіти: аналіз зарубіжних тенденцій. Вища школа. 2005. № 5. С. 89-103.

3. Ковалевская Е.В. Проблемность в преподавании иностранных языков: современное состояние и перспективы : учебник для вузов. Москва : МНПИ, 1999. 120 с.

4. Дичківська I.M. Інноваційні педагогічні технології : навч. посіб. Київ : Академвидав, 2004. 352 с.

5. Швидка H.M., Жданова Н.О. Інтерактивні методи вивчення іноземних мов. URL: http://www.rusnauka.com/12_ENXXI_2011/Pedagogica/2_85239.doc.htm (дата звернення: 19.01.2021).

6. Цареградська К. Аспекти використання методів проблемного навчання у формуванні іншомовної соціокультурної компетенції студентів технічних спеціальностей. URL: https://kamts1.kpi.ua/ node/574 (дата звернення: 19.01.2021).

\section{REFERENCES}

1. Hryshkova R.O. (2007) Formuvannia inshomovnoi sotsiokulturnoi kompetentsii studentiv nefilolohichnykh spetsialnostei [Formation of foreign language socio-cultural competence of students of non-philological specialties]. Mykolaiv : Mykolajivsjkyj derzhavnyj ghumanitarnyj universytet imeni Petra Moghyly. (in Ukrainian)

2. Ziuzina T. (2005) Nauky pro kulturu ta mystetstvo v strukturi humanitarnoi universytetskoi osvity: analiz zarubizhnykh tendentsii [Science of culture and art in the structure of humanitarian university education: analysis of foreign trends]. Higher school, no. 5, pp. 89-103.

3. Kovalevskaia E.V. (1999) Problemnost v prepodavanii inostrannykh yazykov: sovremennoe sostoyanie i perspektivy [Problems in foreign language teaching: Current state and prospects]. Moskva : MNPI. (in Russian)

4. Dychkivska I.M. (2004) Innovatsiini pedahohichni tekhnolohii [Innovative pedagogical technologies]. Kyjiv : Akademvydav. (in Ukrainian)

5. Shvydka N.M., Zhdanova N.O. (2011) Interaktyvni metody vyvchennia inozemnykh mov [Interactive methods of learning foreign languages]. URL: http://www.rusnauka.com/12_ENXXI_2011/ Pedagogica/2_85239.doc.htm (accessed 19 January 2021).

6. Careghradsjkā K. (2011) Aspekty vykorystannja metodiv problemnogho navchannja u formuvanni inshomovnoji sociokuljturnoji kompetenciji studentiv tekhnichnykh specialjnostej [Aspects of the use of problem-based learning methods in the formation of foreign language socio-cultural competence of students of technical specialties.]. URL: https://kamts1.kpi.ua/node/574 (accessed 19 January 2021). 